\title{
CASE STUDIES ON TWO FORTIFIED CITIES IN MONTENEGRO: KOTOR AND ULCINJ
}

\author{
M. RAMELLA GAL \\ SiTI, Polytechnic of Turin, Italy
}

\begin{abstract}
Kotor and Ulcinj, on Montenegrin coast, both played extremely important defensive roles in the past. Both of ancient origin, they had their moment of major development in the Middle Ages, when they were equipped with walls to defend themselves from both maritime and terrestrial activities.

In the Serenissima period the transformations of the defensive structures were implemented in both cities, but Ulcinj ended up being Venetian foundation in 1571 to become a pirate headquarters; Kotor instead, thanks to its strategic geographic position in the bay, remained under the rule of the Venetian Republic until its fall.

Today the original defensive structure of both cities has been conserved and enhanced: if Kotor focuses on the conservation of them as a strategic point for the landscape enhancement, Ulcinj leverages its sublime location overlooking the sea to intercept a maritime tourism.

Both were selected by the Montenegrin Ministry of Culture for the candidacy to the World Heritage List, participating with Croatia and Italy with a serial site.

The international cooperation target is put beside the aim of gaining increased worldwide visibility, definitely promoting the tourist offer but at the same time supporting the aspect of sustainability, participation and training, creating national and international networks to promote research on the fortified architectures.
\end{abstract}

Keywords: fortified city, Montenegro, sea defence, UNESCO, Venetian defence.

\section{INTRODUCTION}

Kotor and Ulcinj are two towns on the Montenegrin coast, lapped by the Adriatic Sea and characterized by a long and troubled history, which has allowed them to become places of great cultural interest. Because of their position they became fortified cities, surrounded by a boundary wall, defensive ramparts and doors constantly controlled militarily. Today they have become the historical centres of the current cities that gradually are extended outside of the walls.

But they are not defined as Montenegrin since long time. In fact, this nation was founded 12 years ago, when it gained independence from Serbia; today it is characterized by a great diversity of people. Their ethnicity, origin, and religion are different, but they are found to be part of a nation that still hardly try to have an internal cohesion. On this basis it is possible to understand how the Montenegro's heritage is still hardly protected and enhanced.

Anyway, today the original defensive structure of both cities has been increasingly conserved and enhanced and there are some maintenance and restoration projects on the historic urban structure within the walls.

\footnotetext{
This paper is part of the Proceedings of the 3rd International Conference on Defence Sites: Heritage and Future (Defence Heritage 2016)

CONFERENCES www.witconferences.com
} 


\section{THE FORTIFIED CITY OF KOTOR}

Kotor is located in the Kotor Bay, an inlet on the Montenegrin coast, which has always been a geographical area of strategic importance with an exceptional geomorphological conformation; the three mutually connected bays - Herceg Novi, Tivat and Kotor - form one of the most safe natural harbours in the Mediterranean Sea. It is along a coastline of about one hundred kilometres that defines a peculiar landscape characterized by the alternation of water and land where the human component and the natural one intersect, forming a mountain and sea mixed and jagged ensemble.

Kotor, placed in the south-eastern part of the bay, at the foot of Mount St Ivan, was the most important outpost of this area. It passed from hand to hand to various population, including the most important one, the Venetians, who maintained it for more than three centuries.

Its fortifications are extremely interesting: the defence took place both from the sea and by land, and through the circuit of walls and bastions that climb up the mountain, creating a landscape absolutely charming and impressive [1].

\subsection{History}

From the historical sources it appears that Kotor has Roman origins, when the settlement was located at an higher altitude than today.

The Kotor walls were built over the centuries, from the time of Byzantine rule, and during the 13th and 14th centuries, they were radically renovated and definitely set as a defensive perimeter of the city.

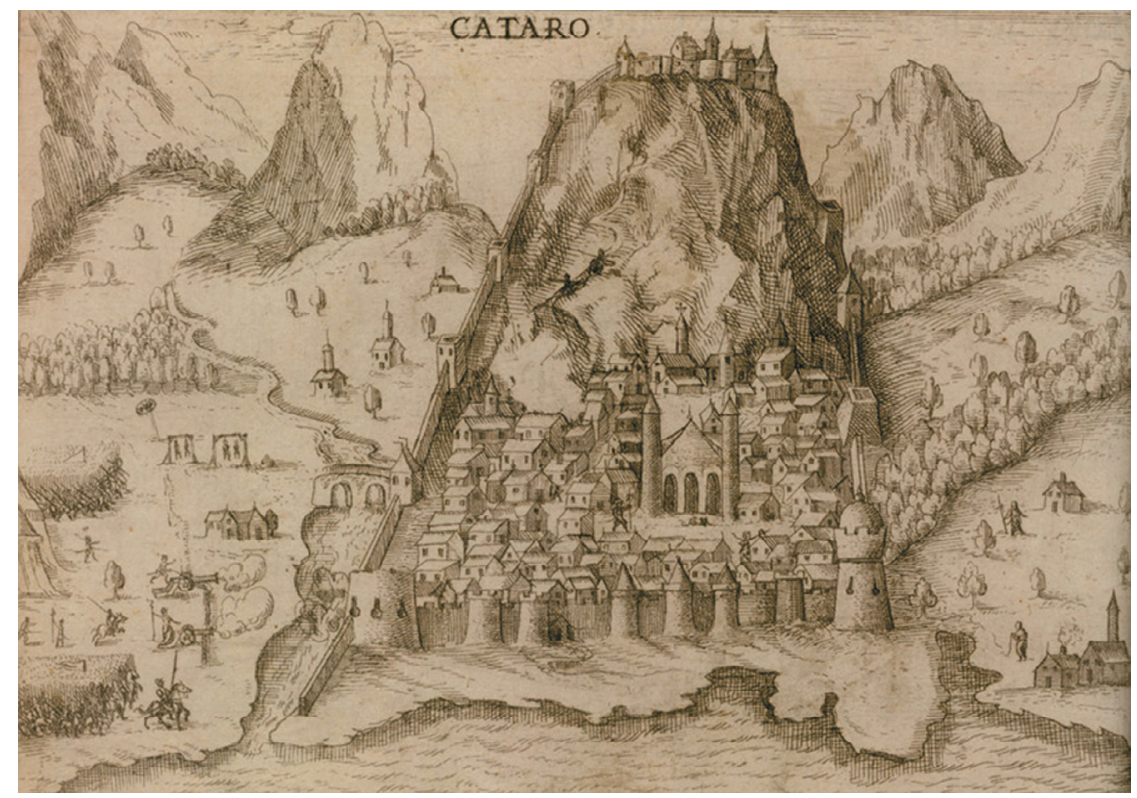

Figure 1: View of Kotor, with the fortress of St John on the top and the massive walls all around the city. Source: H. Beaubau, Relation Iournalière du Voyage du Levant [...], 1615, Hellenic Library - Alexander S. Onassis Public Benefit Foundation. 
It is in fact from the Middle Ages that the actual definite boundary wall begins to delimit the city. Medieval traces are still visible though the Venetians have heavily modified the system to adapt to new techniques of war.

Kotor in fact became a part of the Venetian Republic in 1420. This was particularly significant for the Venetians because of its location (hidden inside the bay) and its strategic geomorphological conformation; the walls defended the attack by sea and by land and the sloping terrain slope allowed to have a prime viewing position of the entire bay. Actually many times it was attacked by enemy populations, especially the Turks, both by land and by sea, always demonstrating their great defensive power [2] (Fig. 1).

Some significant works were undertaken by Venetians in particular by the middle of, and especially in the second half of, the 18th century. At that time there were also other big repairs, and the works to build a defence corridor to Gurdić were undertaken. The walls were also repaired in 1747, and the works were carried out for 14 months. The Venetians ruled here till 1797.

Next, a particularly turbulent period of Kotor, which had a negative impact in the field of architecture and urbanization of the city, came after the fall of Venice, and from the end of the 18th to the early decades of the 20th century, Kotor lived through four foreign occupations: Austrian, Italian and French till it became a country of the Yugoslav state.

\subsection{Description}

The urban layout of the city has a triangular shape due to the geomorphology of the place. It is bordered by two streams: Škurda and Gurdić. The great defensive wall uses these waterways as a further element of defence and then climbs up the mountain until it gets to about 260 metres above the city, where the Fortress St Ivan emerges [3] (Fig. 2).

Along the wall many bastions and ramparts are present to allow a constant monitoring of the surrounding area. Ramparts and platforms for artillery are connected to each other

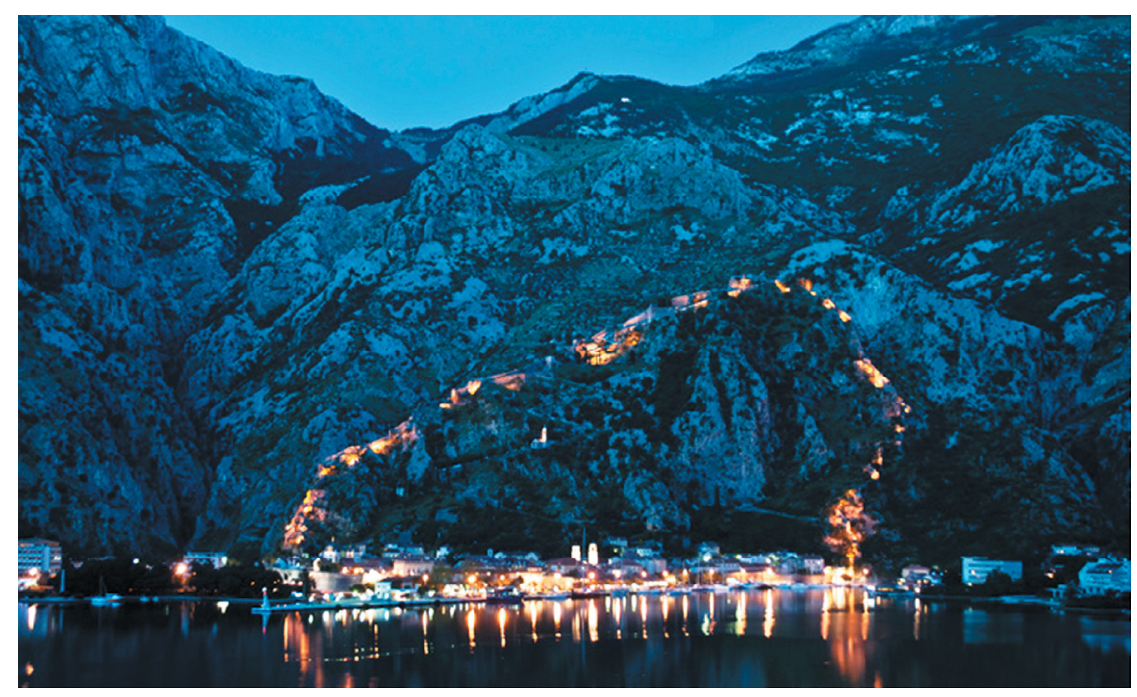

Figure 2: The illuminated walls of Kotor seen from the bay. 


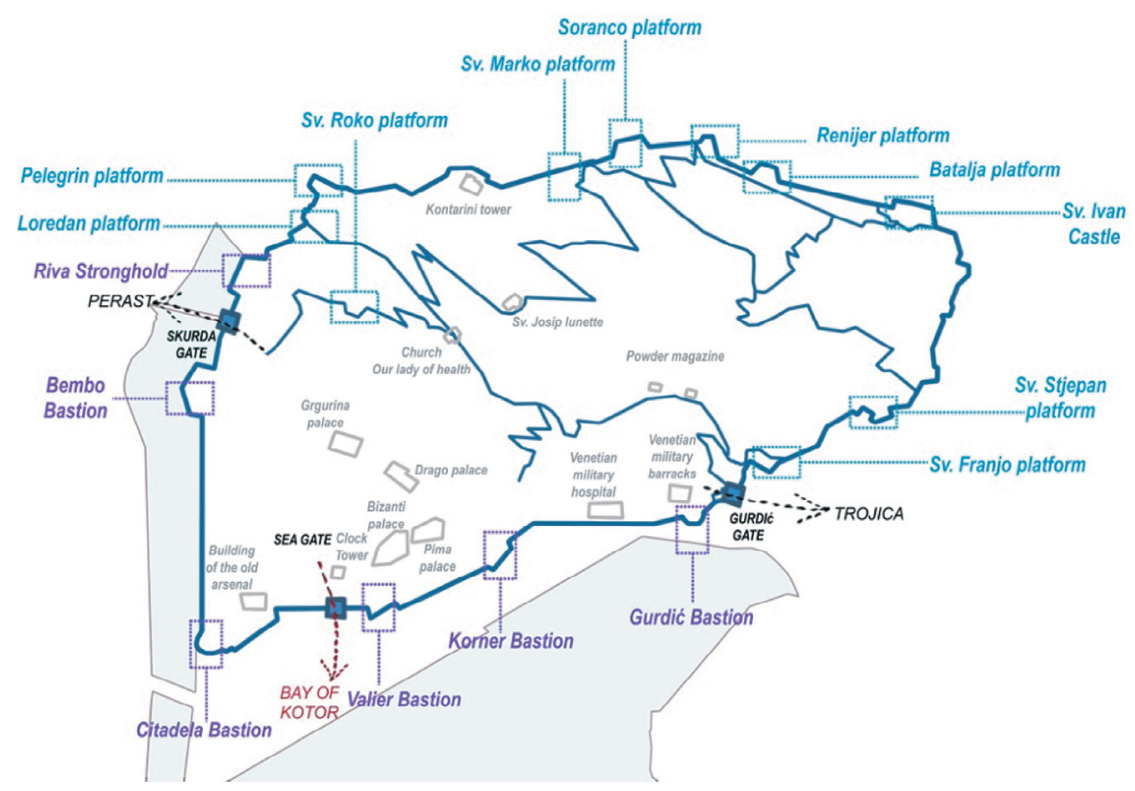

Figure 3: The elements summarized in the city map of Kotor.

and are called Contarini (14th-15th century), Zen, the Great Battle (1768), Renier (1768), Soranzo, Loredan (15th century), Priuli (1767) and Molin, all names of the Venetian supervisors during their service these were built. The ramparts Corner and Valier and the fortification between these ones along the coast were built after the 1667 earthquake; the bastion Corner has been little explored unlike the bastion Valier which has been investigated on several occasions. Inside there are the remains of the medieval fortifications as well as those of a door of Romanesque-Gothic style, dating back to the 14th century [4]. On it was done a project of valorization and cleaning of the Serenissima's symbol: the lion. It is so important that it is found very often in the city: on the buildings, along the walls, on the doors. It is also present on the entrance of the path along the walls; actually today it is possible to follow it and get to the top, from where one can enjoy a breathtaking view of all the bay.

The entrance to the city is possible only through a few doors, three of which are original: Porta Marina, Škurda and Gurdić. The first one allowed the entrance to the city on the water, while the other two were preceded by bridges controlled by stalking on the nearby ramparts.

Internally many historic buildings are still recognizable (although some of them have suffered serious damage caused by the strong earthquake of 1979) such as the Clock Tower (17th century), the Rector's Palace (17th century) and the barracks with corridors and balconies which provide access to individual rooms, the Town Hall, the Arsenal, the Bizanti Palace (17th century), the Pima Palace (17th century), and the Grgurina Palace (15th century), and now Maritime Museum. But there are also the religious buildings such as St Lucas's Church (12th century), St Anna's Church (12th century), St Mary's Church (13th century), St Michael's Church (14th century), Church of Our Lady of Health (16th century) and the impressive Cathedral of Saint Tryphon, with two large facade bell towers (12th century) (Fig. 3).

As already said this setting, strongly attributed to the Serenissima, was effective against numerous Turkish attacks for more than three centuries; the Venetians in fact, with their 
settlement in Kotor, tried to remodel the defences of the city, rebuilding and reinforcing the wall along 4.3 kilometres into the sea with a maximum height of 20 metres and the thickness ranges from 2 to 16 metres. At the time of the appearance of firearms, the high tower was partly reconstructed so as to be more resistant, and platforms for artillery were formed [5].

\section{THE FORTIFIED CITY OF ULCINJ}

Ulcinj is overlooking the sea, on the south of Montenegro, near the border with Albania. Its position has always been strategic, especially as pirate base in the Adriatic.

The feature of the city is to be a small peninsula surrounded almost entirely by the sea, except a flap linked to the mainland.

The Venetian presence in the city was very important for the structure of Ulcinj, actually it has strongly influenced the architecture and the urban design of the city.

\subsection{History}

It is among the oldest cities built on the coast of the Adriatic and, from prehistory to the late 19th century, because of its geographical position, was the object of conquest by many populations. Some stood there a long time, some not, but all have left some traces: from the prehistoric Illyrians, Hellenistics, Romans, Slovenians and Turks till the Venetians.

The territory of Ulcinj, in the centuries preceding the Roman conquest, was inhabited by the Illyrian tribe of Olciniati. Illyrians lived in the region at the time and there are traces

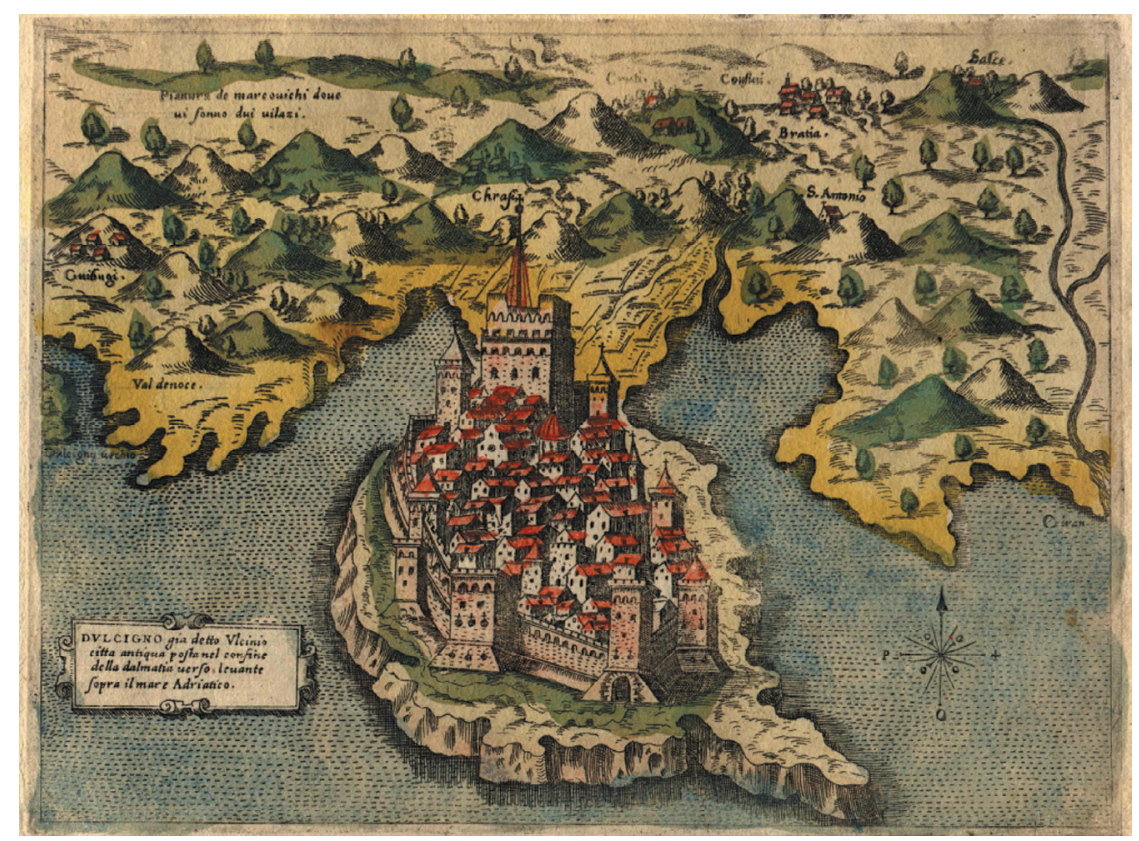

Figure 4: View of Ulcinj published by the Italian Simone Pinargenti. Source: Isole che son da Venetia nella Dalmatia et per tutto l'Arcipelago, fino a Costantinopoli, con le loro Fortezze e con le terre piu notabili di Dalmatia, Venice, 1573, Bibl. Nazionale Centrale Di Firenze. 


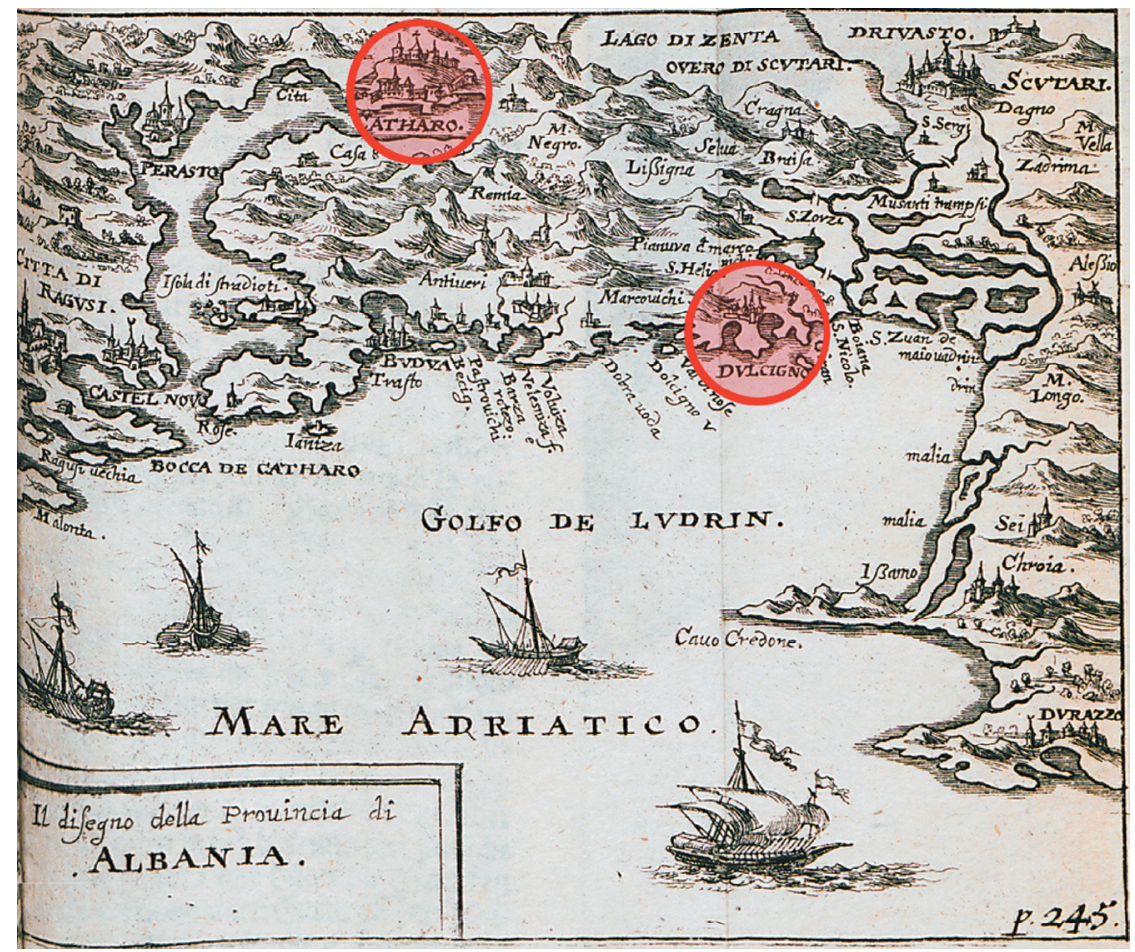

Figure 5: Kotor and Ulcinj, on the Adriatic coast, are here highlighted: they are part of Albania Veneta. Source: J. Von Sandrart, Map of the coast from Kotor, Montenegro to Durrës, Albania, 1687, Gennadius Library - The American School of Classical Studies at Athens.

of immense Cyclopean walls still visible. The town was frequented by Greeks who might have settled their trading centre using the existing port facilities; subsequently it became autonomous municipality with the name of the Roman Olcinium or Ulcinium and played an important commercial role at the crossroads between the hinterland and the opposite shores of the Adriatic, and it so easily acquired the Latin Mediterranean culture. In 1405 the Venetians conquered the town that remained under the Serenissima for 150 years. Under Venetian control, the city was renamed Dulcigno in Italian, and it was incorporated in the Albania Veneta (Fig. 5) (area between the Bay of Kotor and the mouth of the Bojana River) [6]. It had a strategic role as a crossroads between internal city and the sea that makes Ulcinj, in the short period of Venetian rule, a great trading post (Fig. 4).

\subsection{Description}

The most important area of the city is the powerful Cittadella in the form of Acropolis, next to one of the two gates of the city, the terrestrial one (Fig. 6). The significant features are the Balšić tower, the St Marije church, the Custom and the Bishop's Palace. In the north-east of the city, the archaeological remains of the purely military area behind the imposing walls are also interesting: military barracks, gunpowder, stores and tanks. 


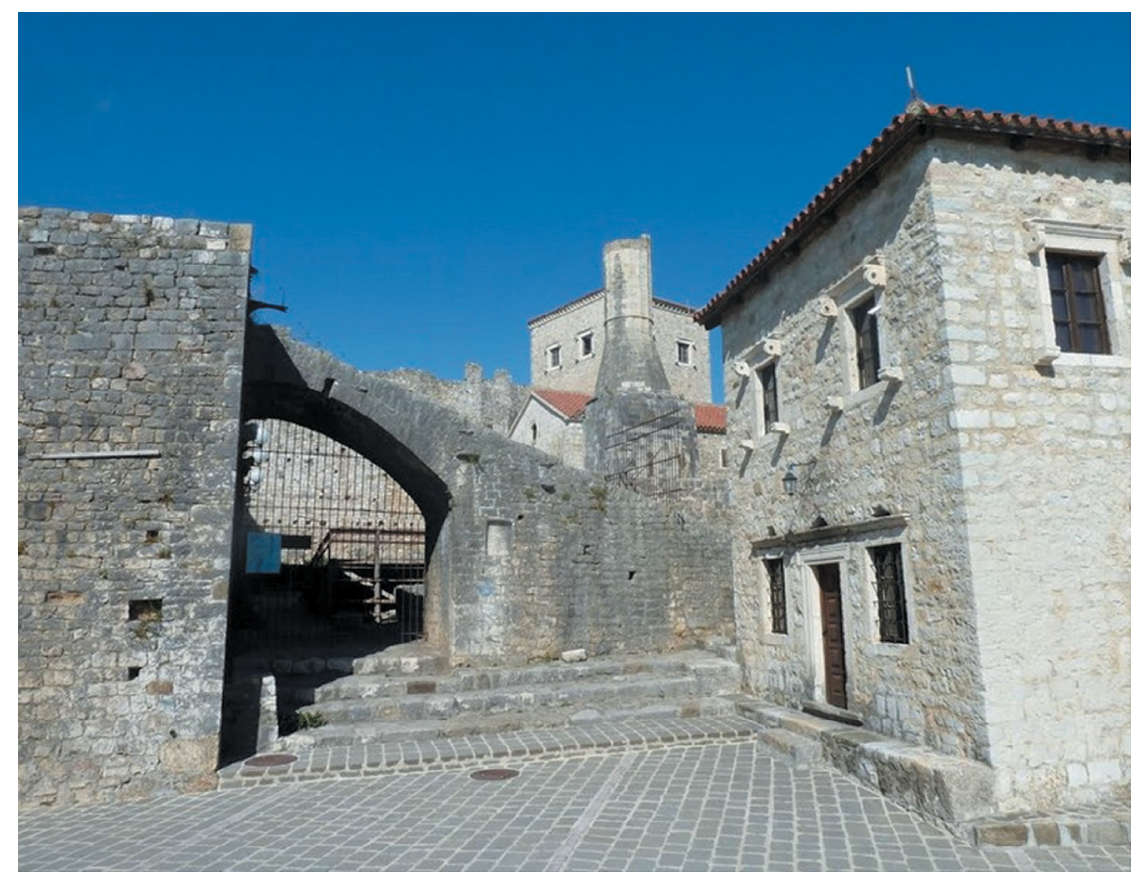

Figure 6: The Cittadella area in Ulcinj.

Today all this area is the city's museum. The church, founded in 1510, in the north area, converted into a mosque by the Ottomans, without changing the typically Venetian characters, contains within it different typical heirlooms: badges, everyday objects, historical maps, decorative elements, jewellery, decorations, etc.

The most interesting part is ancient customs. It is nowadays the head office of the Museum of Ulcinj. The original interior frescoes on the ground floor have been recently restored.

Another important element is the Bishop's Palace. Fresco remains are still present inside. Frames of various openings were precisely reconstructed. Covered passage on the north facade and some openings were changed so that the building can be adapted to new purpose. Currently it hosts the ethnographic section of the museum with interesting remains and documents about the old town. Most of these buildings are scattered around Slaves Square surrounded on the north-east side by the tall Bolani Wall. The wall was signed with the name of Johani Bolani, the Venetian rector and captain of the city between 1452 and 1456. The name has been done with red bricks between the stone blocks of the wall.

All around the city the defensive Venetian walls are preserved in particular in the north and south areas. They are recognizable thanks to the typical linear decoration and cold grey colour limestone blocks, all with a rectangular and regular shape, and united with a little quantity of mortar. This stone was imported from Korcula for rabbets and architectural details. For the beams of the houses and the construction of higher floors they used local wood. Moreover, it is evident the cavalier, a raised earth platform, built on the curtain wall, was designed to mount artillery and to command the surrounding ground. 


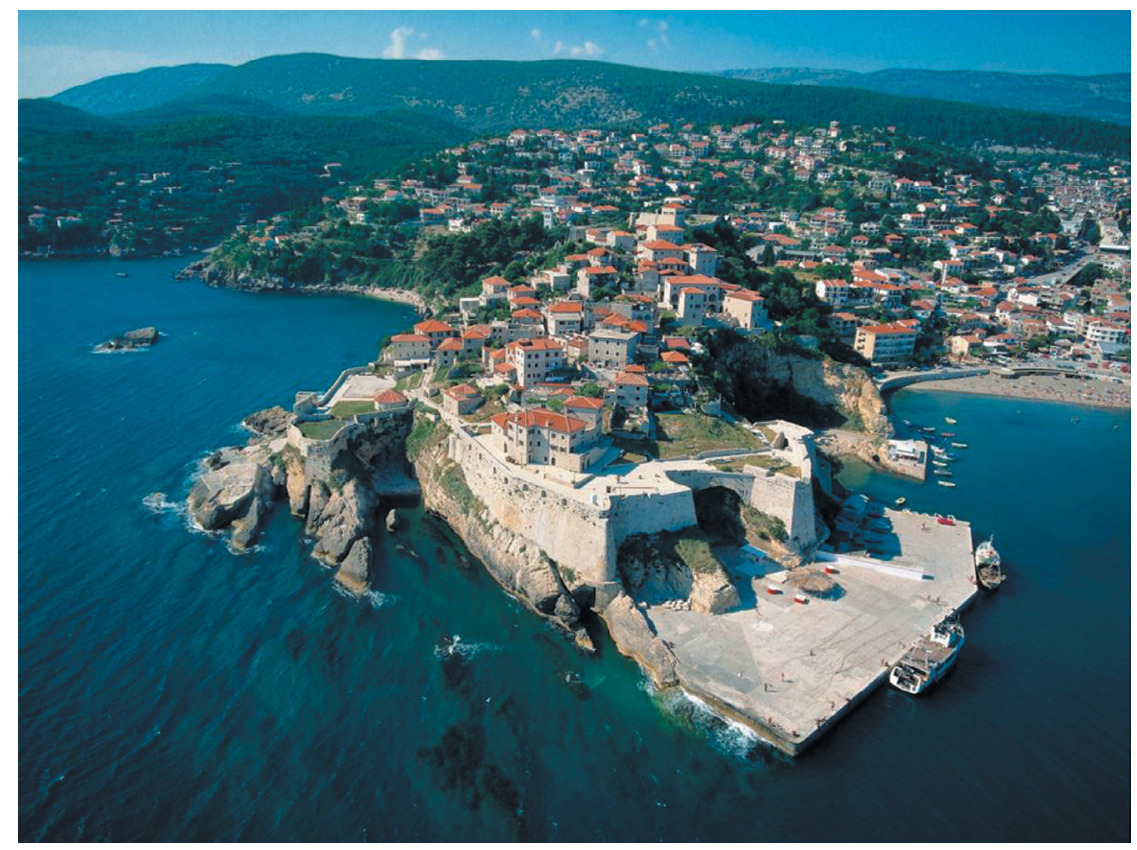

Figure 7: The fortified city of Ulcinj seen from above.

Towards the sea the walls present many buttresses for cannons overlooking the sea and the continuous walkway around the entire defensive perimeter is still visible (Fig. 7). Here, behind the wall, near the second gateway to the city, reachable only after a long flight of stairs, there are archaeological remains of particular interest, in particular a medieval church. It is different from the other one towards the hinterland which has no steps because the goods that were brought from the mainland in the town could be easily transported there.

In this area two important Venetian setting buildings are also identified: the Palata Venetia and Balšić Castle, both hardly restored after a big earthquake. Today the Venetian presence in Ulcinj is clear, thanks to the restoration after the 1979 aforementioned earthquake, because all the intervention has been done, maintaining and preserving all the elements of the Serenissima domain: the palaces, the church, the administration buildings and the defensive elements [7]. They are now enhanced, thanks to the institution of the Local History Museum in Ulcinj, which uses the Venetian buildings as expositive areas, and it is dedicated to the restoration and preservation of the same, and also it pays special attention to exposing all the elements of movable heritage which date back to the Serenissima period.

\section{CRITICAL ISSUES AND POTENTIALITY}

But some negative elements are obvious within these two fortified towns, linked to a general lack of attention to the Montenegrin cultural heritage protection. In fact, tourism is not managed properly, and often the proper maintenance of assets is not performed and sometimes they are not assigned new functions compatible with this kind of cultural heritage.

The Kotor path along the walls is not set, the walls are not all feasible, the new features of some bastions (disco) are questionable and, at the same time, the disuse of other goods could 


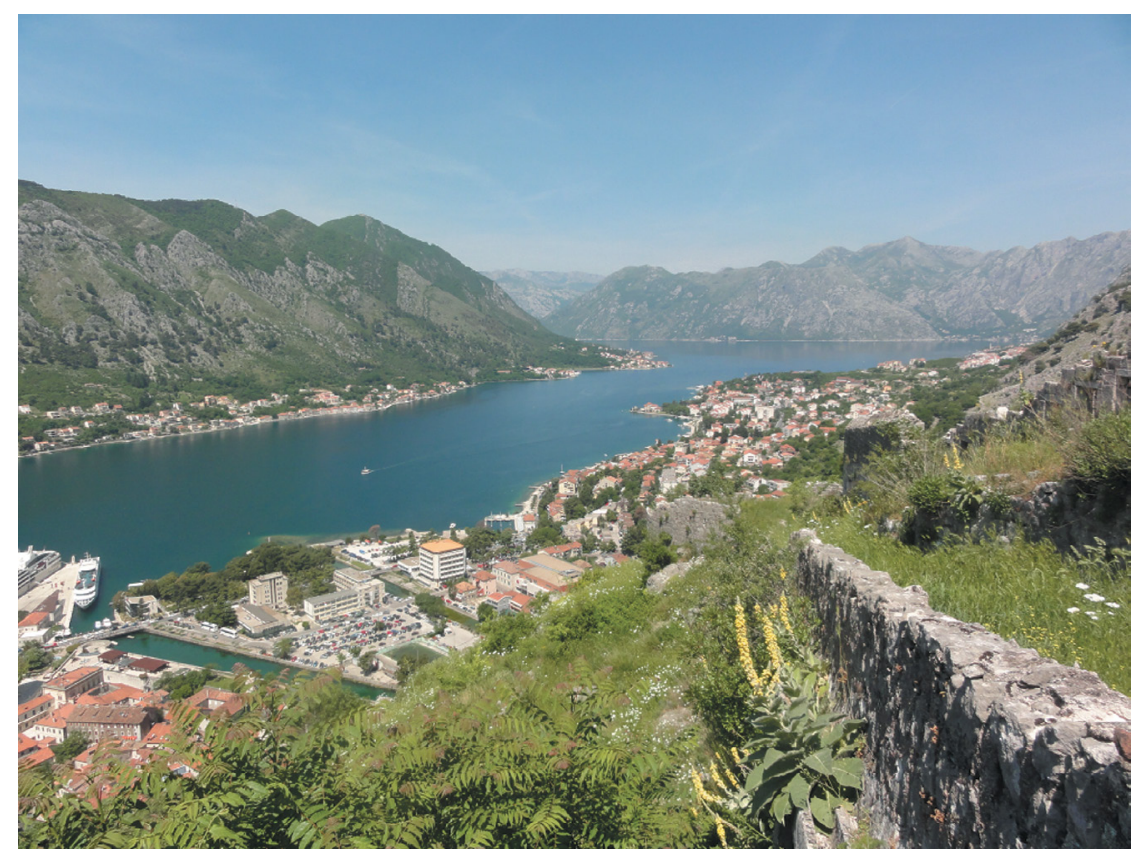

Figure 8: The incredible landscape in which the fortified city is inserted seen from the higher part of the Kotor's walls.

be a negative aspect for the conservation of the cultural heritage. Ulcinj lush vegetation along the walls, the lack of attention to the protection of archaeological sites in the historical centre and the construction of new facilities with inadequate materials and of new architectures divorced with the context are all critical elements.

Moreover, the high seismicity of the place is a big danger for both the cities, so plans for the protection of cultural heritage in case of seismic risk are necessary.

In both cases there is no sensitivity landscaping because there is difficulty seeing the architectural or urban object in its context: Kotor in the Boka Bay, and Ulcinj in its coastal area (Fig. 8).

Something is being done about it; actually the first important step has been the recent realization of the spatial plan for the landscape protection.

Many positive aspects, however, are already noteworthy and contribute to the protection of these places: the impossibility of vehicular traffic inside the two historical centres, the maritime tourism already developed in the surrounding areas that can be easily attracted to these cultural centres and the entry of these sites within an international circuit.

\section{A NEW PATH JUST BEGAN: NEW PERSPECTIVES FOR THE FUTURE}

Actually, the two described sites were selected by the Ministry of Montenegro to become part of a transnational serial site along with Croatia and Italy. The application has been recently submitted to UNESCO and concerns 'The Venetian Works of defense between 15th and 17th centuries' [8].

International cooperation will certainly help the two cities. Being part of a network allows sharing of good practices between different sites and, at the same time, a promotion of them to each other. The aim of a transnational network is in fact a growing tourism, gaining 
international exposure, not losing sight of the cultural heritage sustainability, in order to preserve the assets in good conditions for the future generations.

But ties with other states also allow an improvement in the level of conservation practices, triggering a process of study, protection and final enhancement. The attention of scholars is drawn to these sparsely attended areas, particularly to issues of maritime military architectures that dot the entire coast of Montenegro (not only Kotor and Ulcinj but also Budva, Herceg Novi, Bar and Perast). A protection process, that UNESCO requires to become a world heritage site, is implemented; the sites involved are enhanced through new projects, events, and interventions on cultural assets.

It is essential to give an opportunity to the local population to regain possession of their territory. The participation of citizens, involvement of different authorities, cooperation of the younger generation and promotion of tourism allow local people to gain a greater awareness of its assets, its traditions, origins and all those values that have characterized the place of which they themselves are the protagonists.

It is important to recognize the resources of these locations, starting to consider the economic potential of the types of goods linked to the different kind of tourism: the mass one that takes advantage of the summer seaside offer but that may also be attracted by the cultural elements; the niche one, which focuses on the heritage, on the history and on the scenic beauty of the places; the slow one, for quiet holidays, focusing on local beauties, on food and wine, and on the healthy and natural appearance. Always taking into account the strong impetus given by the international resonance, which is possible only through continuous cooperation with other countries, trying to expand the network of contacts allows to increase the knowledge of these places internationally.

Kotor and Ulcinj represent a starting point from which one can begin to think about similar issues concerning the entire defence assets with which the Montenegrin coast is well supplied and also about giving new compatible features, new forms of protection and an enhancement that is conducive to cultural heritage itself; this in turn will also benefit the same population.

\section{REFERENCES}

[1] Lalosevic, I., Bay of Kotor Venetian period (1420-1797) military architecture. L'architettura militare di Venezia in terraferma e in Adriatico fra XVI e XVII secolo, ed. F. P. Fiore, Leo S. Olschki Editore: Firenze, pp. 335-357, 2014.

[2] Molteni, E. \& Concina, E., 'La Fabrica della fortezza', L'architettura militare di Venezia, Banca Popolare di Verona - Banco San Geminiano e San Prospero: Modena, pp. 253-261, 2001.

[3] Marchesi, P., Fortezze veneziane: 1508-1797, Rusconi: Milano, pp. 121-129, 1984.

[4] Lalosevic, I., Kotor Fortress, Studies, Conservation and Revitalisation, Regionalni zavod za zastitu spomenika kulture Kotor: Kotor, pp. 6-24, 2003.

[5] Crevato Selvaggi, B., Martinovic Jovan, J. \& Sferra, D., L'Albania veneta. La Serenissima e le sue popolazioni nel cuore dei balcani, Biblion: Milano, p. 18, 2012.

[6] Nadin, L., Venezia e Albania, una storia di incontri e secolari legami, Regione veneto: Venezia, p. 17, 2013.

[7] Boskovic, D., Mijovic, P. \& Kovacevic, M., Ulcinj I, Institut Archeologique: Beograd, pp. 153-161, 1981.

[8] The Venetian Works of Defense between 15th and 17th Centuries, Nomination Dossier: Bergamo, 2016. 